\title{
4. Big Wok: The Vanuatu Cultural Centre's World War Two Ethnohistory Project
}

\section{Lamont Lindstrom}

By the 1980s, it was clear that the generation of older ni-Vanuatu that had experienced the remarkable and sometimes traumatic events of the Pacific War was passing away. Sponsored by the Vanuatu Cultural Centre (VCC), with support from the U.S. National Science Foundation and the Wenner-Gren Foundation for Anthropological Research, VCC fieldworkers between 1987 and 1989 interviewed more than 125 men and women who had lived through the war years in Vanuatu (1942-1946). Coordinated by James Gwero and Lamont Lindstrom, the project attempted to locate and interview throughout Vanuatu men and women with stories to tell. ${ }^{1}$ A selection of these recorded accounts subsequently appeared in a book Big Wok: Storian blong Wol Wo Tu long Vanuatu, published entirely in Bislama (Lindstrom and Gwero 1998; for a second collection of war history in Vanuatu, see Moon and Moon 1998). The project also produced a weekly program for Radio Vanuatu in late 1988 and early 1989. The project's upcoming twentieth anniversary invites us to recall some lessons learned. War stories, and their collection, can tell us something about research collaboration and about Vanuatu's stories, storytelling, and storytellers in general.

The World War Two Project, which involved chasing down older men and women with stories to tell from Aneityum up to the Torres Islands, was certainly Big Work. Actually, we chose the name Big Wok to reflect that of a similar project of Pacific War ethnohistory then ongoing in the Solomon Islands. This had produced a collection of war memories called Bikfala Faet: Olgeta Solomon Aelanda Rimembarem Wol Wo Tu (The Big Death) (White et al. 1988). The Solomon Islands suffered months of violent land and sea battles. Down in Vanuatu, which was spared much actual fighting, most people's lives were instead shaken by the establishment of extensive Allied military installations on Espiritu Santo and Efate and also smaller coast-watching and other northern outposts located up through the Torres Islands. Whereas Solomon Islanders witnessed and sometimes were caught up in fighting, most ni-Vanuatu instead

\footnotetext{
1 Although coordinated by Gwero and Lindstrom, various Cultural Centre fieldworkers also helped record war stories and focused on war history during one annual fieldworker workshop. Vianney Atpatoun, Dickinson Dick, Joel Iau, Richard Leona, George Loren, Michael Matoa, Hosea Meal, Mathias Batick, John Peter, Phillip Tepahae, Lengi Tepu, and James Teslo, among others, recorded war stories while Cultural Centre Directors Kirk Huffman and later Ralph Regenvanu helped with project logistics and the eventual publication of Big Wok.
} 
found themselves working, officially and unofficially, for military strangers. Wartime work, thus, was the main focus of our story collecting protocol-or the list of questions that guided our interviews with those who remembered the war.

\section{Storytellers}

Outside military forces began to arrive in Vanuatu in early 1942. Anyone born in 1940 and before, therefore, might have interesting war stories to tell. This was a sizeable percentage of Vanuatu's population - in 1987, any man or woman who was older than 47 years or so. Even if they stayed at home, anyone then living in the country must have noticed at least some impact of the war given the size of military occupation forces (Figure 4.1). In July, 1944 when Allied base operations peaked, up to 100,000 Americans were stationed in Vanuatu or were there in transit to the north (Lindstrom 1996: 11). Since Vanuatu's population was then roughly only 40,000, military personnel, mostly American, outnumbered ni-Vanuatu by more than two to one.

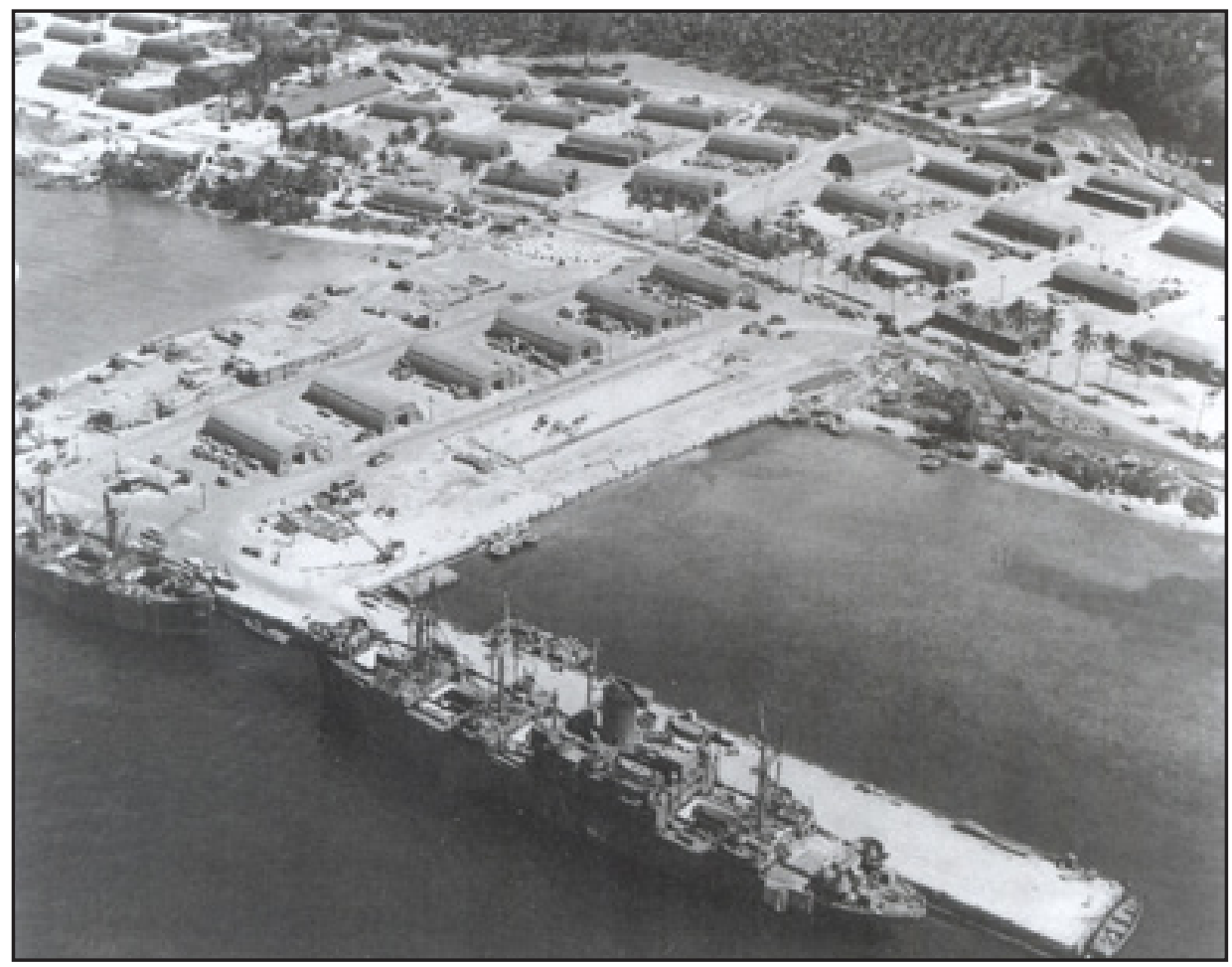

Figure 4.1. Santo, March 1944

(US National Archives) 
With so many potential storytellers, how could we choose who to interview? Local knowledge helped. The VCC fieldworker program - which had many previous successes investigating joint cultural and historical topics throughout Vanuatu-promised to be an effective mechanism for widespread story collection. James Gwero and I started with elder men known for their narrative repertoires of which war stories were often only a small part. Some of these, like Erakor's Dick Lautu, were recognised locally as raconteurs of war history. We recruited storytellers through 'snowballing': asking each storyteller if he or she knew of others from whom we might request an interview. To spread as wide a net as possible, we relied on interested fieldworkers to record who they thought might be most knowledgeable (and most talkative) about war events. Although James and I recorded stories only on Efate, Southeast Santo, West Ambae, and Tanna, we had the support of VCC fieldworkers who found and interviewed people from across much of the rest of Vanuatu. Focusing our efforts on Vanuatu's two towns, we were also able to interview people from a variety of communities who were then present either in Vila or Luganville. We all followed local roads and connections to identify potential storytellers. For example, I called on friends from Southeast Tanna, including Thomas Nouar and Rabi Timo whose war experiences I had already recorded in the early 1980s (Lindstrom 1989). James Gwero, similarly, was interested to document the memories of his kinsmen Timothy Tako and Alfred Coulon, among others. In the end, the particular assemblage of war stories certainly reflected the personal networks of us story collectors.

As an outsider to Vanuatu society, I suspect I was more concerned, compared with some VCC fieldworkers, to pursue story content rather than some specific storyteller. If I could get a good account of Black Americans who served in the New Hebrides, I did not care who might be telling this. But it may be that particular storyteller identity weighed more heavily with some fieldworkers who tapped the memories of elders in their own families and villages. Others, too, were concerned with who was telling stories. During an eight-day recording trip to Tanna, for example, I was accompanied by an assistant nominated by the ministry in charge of cultural affairs whose presence, I suspect, insured that I talked mostly with reliable (in those days, non-John Frum) elders. I was happy to do so, however, as the personal roads that we followed led me to new storytellers around Lenakel on West Tanna.

In addition, I suspect that I was more interested than some in seeking women's war stories. Although we strongly recommended that fieldworkers talk with as many women as possible, in the end the project recorded only eight women of which just one of these was not interviewed by James Gwero or myself. It was true that many women were reluctant to share their memories, deferring to men who might speak for them. Nana Ouchida, for example, was able to talk about the arrest of her Japanese common-law husband but she was much helped 
in this by her son Henri. Similarly, Tom Kalsirik recounted to us the painful rape of his wife who was either still unable to speak about this experience or was prepared to let her husband speak for her. Other women, however, such as Margaret Kastin of Port Vila, were excellent storytellers. One of the best storytelling sessions we recorded involved a group of four women from MeleLeiboe Kalosike, Janet Mansale, Fepi Mara and Annie Kaltiua - all of whom had worked at the Navy hospital established on Bellevue plantation. Sitting together around a table, their stories and laughing memories built one upon the other. We should have tried to record women in similar sorts of groups who might have become more talkative, more reminiscent, in numbers.

\section{Story collecting}

The World War Two Project built on previous research into the war that the VCC and also Radio Vanuatu had begun in the 1980s. ${ }^{2}$ We also benefitted from the work of interested local experts such as Reece Discombe and Ernie Reid. The project's aim was to be as catholic and comprehensive as possible - to collect any sort of war memory that still lingered in the mind of anyone who might be willing to share this. We wanted story topics to emerge from individual and shared memory. What, in particular, were people bothering to remember of their war years? Nonetheless, we had to guess what at least some stories might be about and we approached story collecting with a protocol of issues and questions already in hand. Partly, this had served to convince funders (such as NSF and the Wenner-Gren Foundation for Anthropological Research) to support the project. And partly, this provided our crew of story collectors a shared starting point. The challenge, of course, was not to let our protocol overrun or drown out the themes that local stories and storytellers themselves might reveal. We told the Wenner-Gren Foundation that the project would

address the question of why war stories and songs continue to capture the imagination of local audiences in island Melanesia. In so doing, we seek to understand the socially meaningful statements war stories make about identity, about power, and about relations between islands and others.

We hoped to determine the continuing importance of war stories within individual life histories, local notions of time and history, and war stories' relationship with other genres of island narrative and song. Specifically, we argued that war stories would reveal details of people's military employment and other interaction with outside forces, give insight into the social importance of the presence of many African-American servicemen, and provide information about the emergence of nationalism and other postwar movements in Vanuatu and beyond.

2 Including a James Gwero interview with Aviu Koli of Lamen Bay, Epi. 
We developed a handwritten protocol of story topics, large and small, that we taped to the wall of the World War Two 'office' that was located in the old Cultural Centre building. This rolling protocol, which we added to as needed, listed a set of topics we thought were good starting places when asking people to remember the war and eliciting good stories. These topics ran from various sorts of 'Wok long Amerika' (long dok, sip, efil, rod, hotel, haospital), to 'Halpem Amerika', the New Hebrides Defence Force, 'Niufala samting blong wo', 'Amerika halpem olgeta', 'Niufala bisnis', 'Skul/Jaj', 'Taem wo i finis', and ending up in some miscellaneous 'Trabol long $w o$ '. We tried to use this protocol as a shared starting place for collecting stories. The protocol allowed us to prompt storytellers when memory had, at least temporarily, run its course and also insured that we asked a range of people about what we suspected might have been shared experience. This helped broaden the perspective on particular events insofar as we asked people from throughout Vanuatu, men and women when we could get them, many of the same questions.

It is clear, however, that some of this protocol reflected my outside, in this case American, agenda as much as it did local concern. For example, I had long been interested in the Black American military experience in Vanuatu and I hoped to learn more about this from the local perspective. I was also already interested in the impact of American cargo, supplies, and presence on Tanna's John Frum movement and in the place of 'America' in general within Vanuatu's postwar anti-colonialism. I wanted to be careful, though, not to typecast the influence of some obviously "good" America of the 1940s vis-à-vis the 'bad' colonial powers France and Great Britain. ${ }^{3}$ But other items on our rolling protocol did surface from local memories and stories and not from our outside interests. Some locally well-known events found their way onto the protocol because of sharp, island memories of American doctors who excised one person's filariasisinfected scrotum, the assault, murder, and rape of Maevo and his family by U.S. soldiers that took place near Santo's Sarakata River, and the postwar retrieval of American bodies that had been temporarily buried at Freswota near Port Vila.

Other Vanuatu themes soon became clear as the archive of recorded war narratives grew and we added these, too, to the protocol. Such themes included the various sorts of trouble and suffering that people had endured during the war years and the fact that ni-Vanuatu assisted military personnel (contributing labour, serving as scouts and guides, and more) as much as soldiers and sailors helped ni-Vanuatu (with food, money, medicine, and so forth). As always in Vanuatu, the exchange of goods and services is properly balanced.

3 See Zeleneitz and Saito (1989) for an analysis of the impact of the story collector's nationality on Papua New Guinean appreciation of American versus Japanese forces. 
We also had gathered a small collection of official and private photographs from the 1940s. We showed these around as widely as possible in order to identify, if we could, the people captured in the pictures, and to spark memories about the events portrayed or similar events that people had experienced. For example, Captain Stephen Slaughter, who had worked with Tannese Labor Corps recruits encamped at Tagabe, gave us his wartime scrapbook. Joe Natuman was able to identify the men in several of these photographs. One captures Labor Corp boss Major George Riser along with Tannese labor supervisors Loumhan Isaac, Johnson Kiel, and Simon Nuvo (Figure 4.2). One of my favourite photographs, this one an official U.S. Navy shot, depicts military dentists checking the teeth of a small boy in August, 1943 (Figure 4.3). Titus Molirani of Tutuba recognised himself and his teeth in this some 45-years later. Official U.S. military photographs typically identify the Americans depicted but refer to others only as 'natives' or 'islanders'. My aim to identify, by name, all the individuals depicted in these photographs reflected my own interests but these, I think, were often also shared by many ni-Vanuatu storytellers. Even when no one could put a name to some of the people depicted, photos nonetheless were very useful spurs to memory, evoking much interest and often good stories.

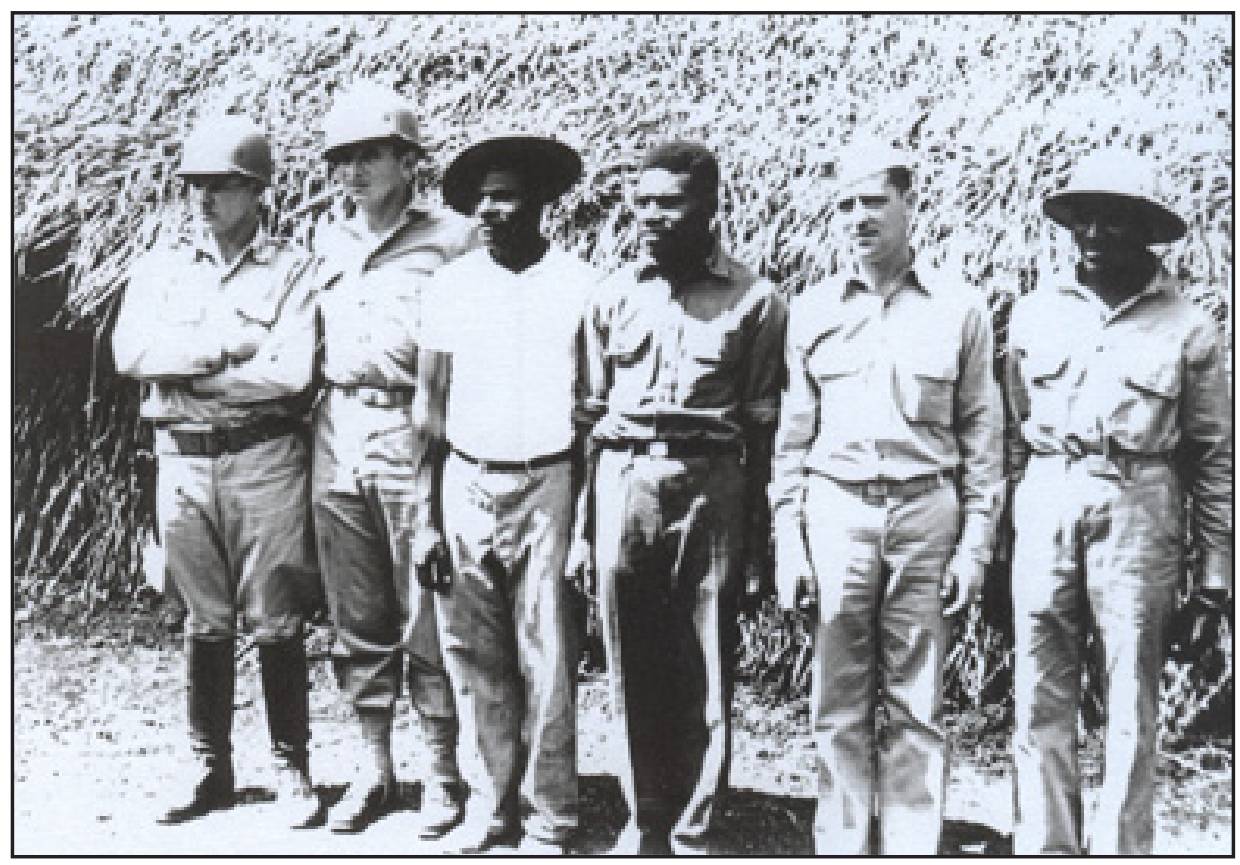

Figure 4.2. American labor corps supervisors including George Riser with Loumhan Isaac, Johnson Kiel, and Simon Nuvo

(S.D. Slaughter photographer; copyright Lamont Lindstrom) 


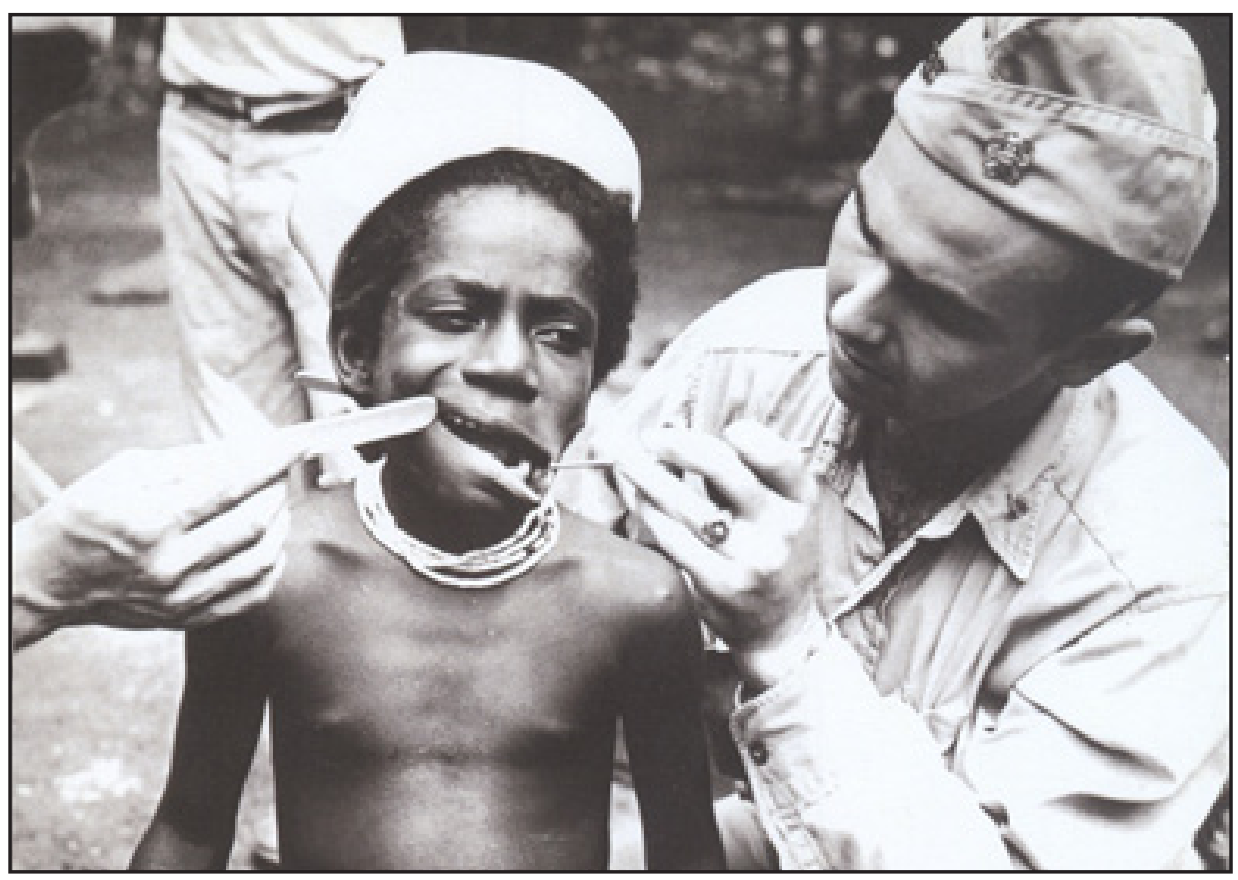

Figure 4.3. Titus Molirani

(US National Archives)

\section{Storytelling}

The other side of story collecting is storytelling. We recorded most stories in Bislama. Those few that came to us in vernacular languages required translation into Bislama (by me, for several stories told in Tanna's Kwamera (Nife) language, James Gwero for a couple of West Ambae stories, or by Vanuatu Cultural Centre (VCC) fieldworkers). I argued then that Bislama was an appropriate language for telling war stories in that the wartime events that people endured were often novel, unknown in kastom, and that the war had brought together people from many communities who, in the 1940s, had to speak Bislama among themselves and also, occasionally, with interested Allied military personnel. I believe these arguments are still good ones and our Pidgin recordings, moreover, were easily transformed into a Bislama book that today is accessible to most ni-Vanuatu who can read the language.

One issue that is always topmost in Vanuatu storytelling is who owns the story? Who has rights to narrate this in public? And who has rights to hear the story? This is particularly so with kastom stories, whose copyright - the right publicly to tell-is frequently owned by individuals acting as representatives of family groups (see Lindstrom 1990: 76-82). We expected most war stories, however, 
still to be 'life stories', or narratives of personal experience (see Lacey 1984). As such, individual storytellers would have best rights to their own stories and they could decide whether or not they might want to share these with us. In some cases, many people had taken part in the same events and had their own perspectives on these. In others, a war story might already have been told and retold to become widely known. These narratives, through previous tellings, have become formalised - additions to Vanuatu's public domain which, of course, remains bounded and by local and kin claims. A number of men, for example, told similar stories about the attack on Maevo and his family near the Sarakata River (see also Moon 1998: 104-06). And many Tannese could tell of Kauas' wild escape from Labor Corps duties on Efate when he put on a nambas and disappeared into the bush. We figured, therefore, that most war stories - unlike many kastom stories - either still belong to the individual narrators who experienced or witnessed the events in question, or like many folktales and children's stories were 'free', belonging to ni-Vanuatu in common. We also supposed shared rights to listen to and record war stories. These are stories about the impact of a global war on ni-Vanuatu lives and land in which many others were also deeply involved including Americans, Australians, New Zealanders, Japanese, British, and French. The appropriate audience for Vanuatu war stories, thus, is far wider than that for many kastom stories that properly speak only to those with kin-based or other local rights to tell, listen, and learn.

Our arguments about 'free' stories, along with relatively meagre project funds, dictated that we did not pay people to tell their stories but only asked them to share them with us. We did promise storytellers an eventual larger audience. We were able to include a number of voices on a weekly Radio Vanuatu program that featured war narratives and song. We also explained that we expected to use stories in a book about the war in Vanuatu. We were careful therefore to ensure that Big Wok, when this finally appeared ten years after the project ended, does include at least a brief comment from almost every storyteller that we recorded between 1987 and 1989.

James Gwero was right to insist that storytellers were as important as the stories they told. Building on James' appreciation of the storyteller and the story, and ni-Vanuatu concern with establishing personal connections between storytellers and story collectors, where we could we photographed storytellers and subsequently shared around copies of these photographs. ${ }^{4}$ These served as small gifts in return for a story. Some storytellers carefully posed in kastom finery (as did Timothy Tako and Matthias Vira of Ambae) or in wartime duds and equipment that they had saved since the 1940s (as did Samuel Tapahan of Tanna, Figure 4.4).

4 I believe that James, at one time, hoped to feature photographs of our storytellers along with their published texts. When we pulled together Big Wok, however, we only included war-era photographs of which only a few of which captured storytellers in their younger years. 
4. Big Wok: The Vanuatu Cultural Centre's World War Two Ethnohistory Project

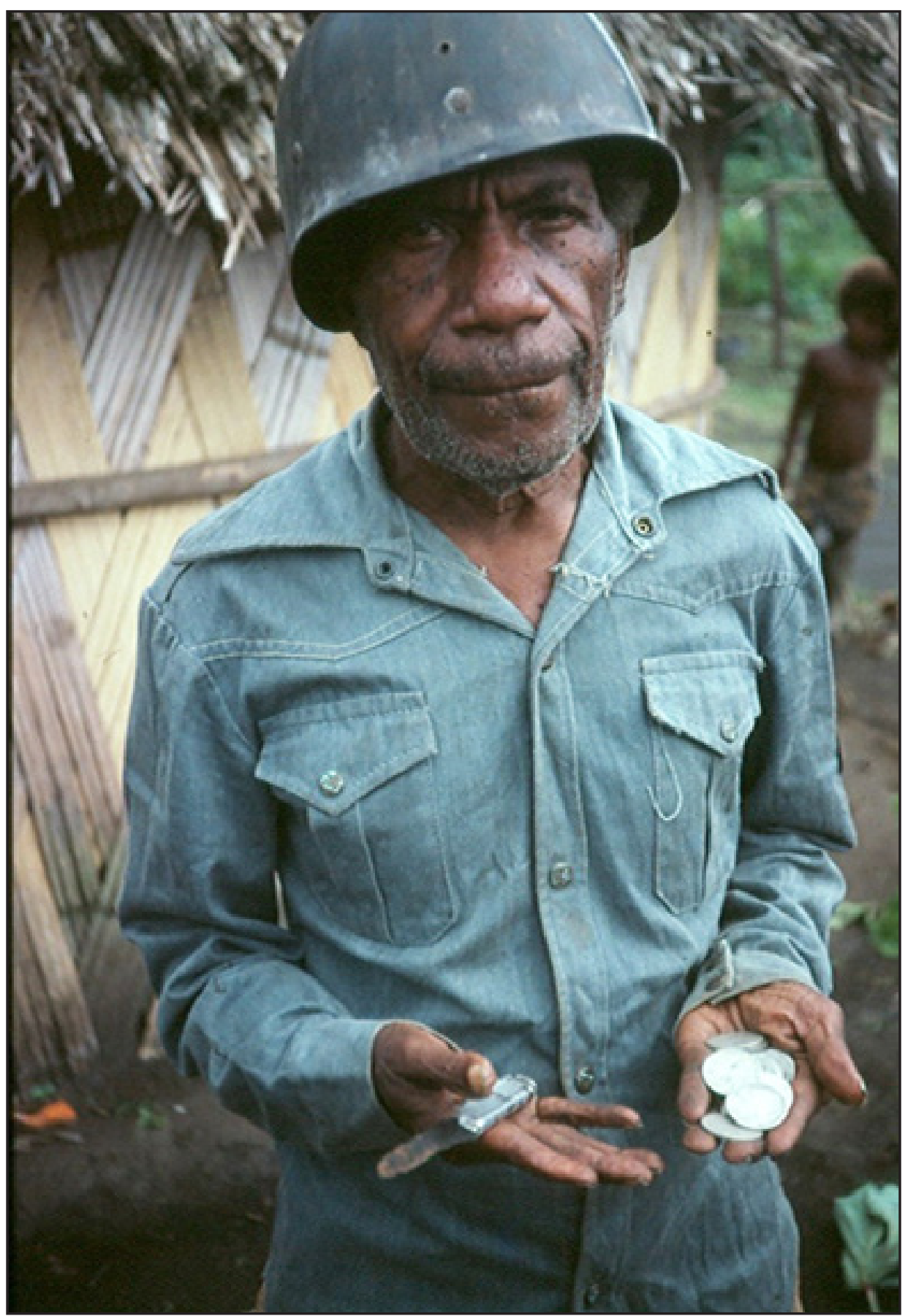

Figure 4.4. Samuel Tapahan

(Lamont Lindstrom, photographer) 


\section{Stories}

War stories differ from kastom stories in various ways including the fact that many of these still remain personal narratives that have not yet been formalised into oral texts, told and retold from one generation to the next. Some of the stories we collected were tightly structured and had clearly been shared before. Other storytellers provided looser, more rambling recollections as they paused to think back to what had happened to them during the war. Most had interesting, often gripping wartime memories whether or not their narratives were tightly or loosely structured. Occasionally, tape-recorder running, someone ran out of memory and James Gwero might then pepper them with questions from the Project's protocol.

Although less formulaic than many kastom stories, war and kastom narratives also have several things in common. Like many kastom stories, war narratives might possibly serve as charters or claims. Just as people tell kastom stories to assert their family's claim to land, to chiefly status, to rights to use certain weaving designs and motifs, and so forth, so might the telling of a war story stake claims. An obvious claim is that the storyteller either personally experienced or witnessed the events that he or she narrates. But stories can also stake more complex, more serious and expensive claims. When Vanuatu sought to assert its territorial rights to Matthew and Hunter Islands, located between Aneityum and New Caledonia, for example, it collected TAFEA kastom stories about these islands.

The counterpart World War Two ethnohistory project in the Solomon Islands, in fact, had sparked much local interest in possible compensation payments from the Americans, British, and/or the Japanese governments. People there sometimes told stories of suffering bombings, death, and destruction hoping that these stories could charter claims to rights to compensation. Perhaps someone at last would pay for bulldozing gardens and trees? Many people in Vanuatu also suffered during the war. A few lost their lives through accidents, illness, or overwork. Some women were raped or assaulted. Some surrendered their homes and gardens to the military, such as happened on Tutuba. Many worked hard for relatively little pay (Figure 4.5). However, we told storytellers that the project was not connected with any official interest in compensating wartime suffering but that we could help, at least, to publicise any stories and painful memories of loss that people might wish to share.

War stories possess other common features with kastom stories. These include the narrative importance of recollecting specific personal and place names. Memories of ancestral names and the places where one's family has lived are obviously important to stake claims to land and other rights. War storytellers, 
along these lines, similarly contextualised their narratives of wartime events within frames of places and people, as did Stephen Vusi of Longana, Ambae, who when interviewed by James Gwero anchored his story with the names of his supervisor Mr. White, military chaplain Mr. Brown, named places such as Bihu, Lolowai, Surunda, Chapuis, and Walaha along with other named people and places. These citations of personal and place names help establish the truth and the weight of what one has to say (see Lacey 1980: 84). ${ }^{5}$

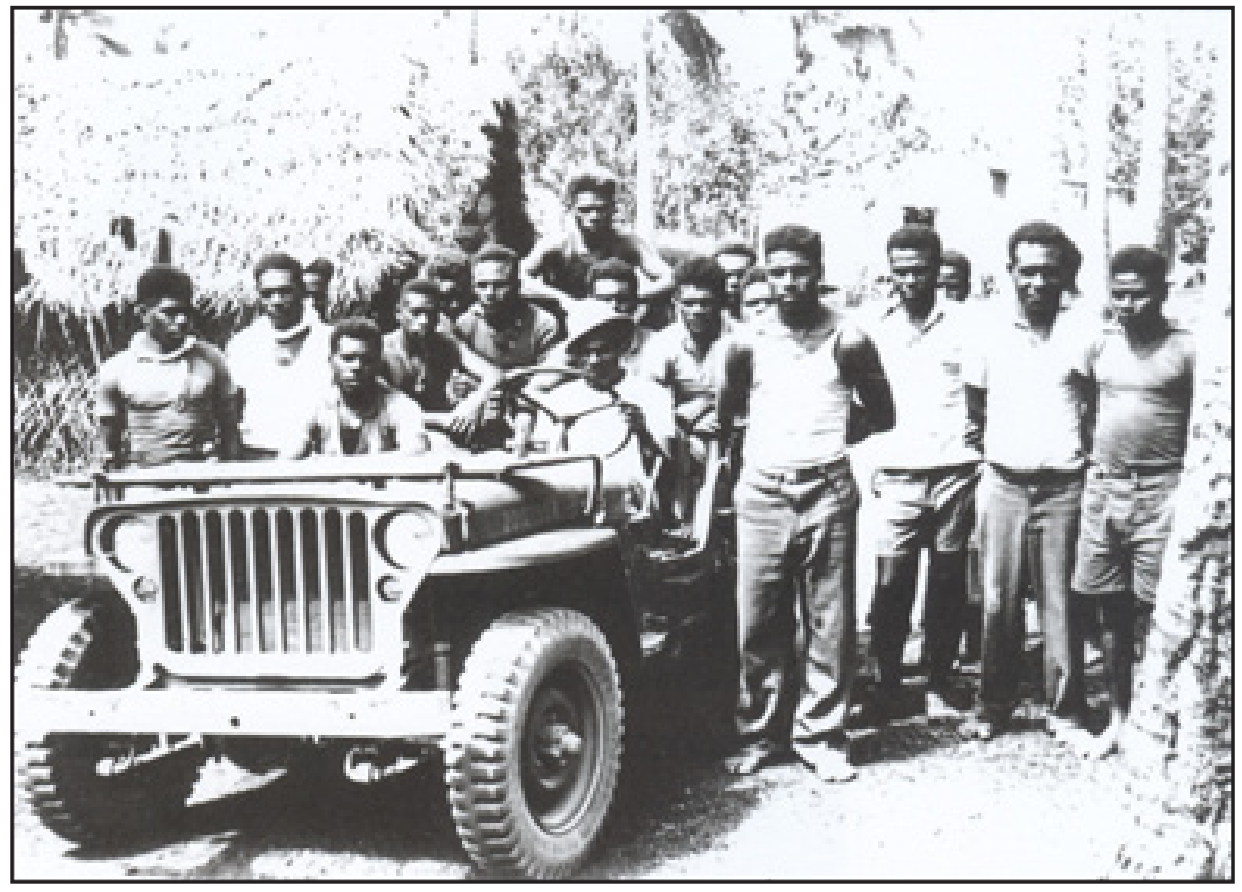

Figure 4.5. Tannese labor corps members camped at Tagabe

(S.D. Slaughter, photographer; copyright Lamont Lindstrom)

Like many kastom stories that celebrate the accomplishments of ancestral or culture heroes, war stories too have champions; many with magical or special powers (see Lacey 1984: 13). One kastom-like hero, mentioned by several storytellers, was Santo resident Leon Giovanni. Giovanni served as ships' pilot and he also guided several US military patrols into the Malakulan bush and elsewhere. Local storytellers, however, were more interested to recall his special powers, especially those associated with su magic. Giovanni could make himself invisible and also discover hidden Japanese scouts and spies that no one else could see. Solomon Marakon of Ambrym recalled: 'Leon Giovanni, him i gat samting ya, him i gat su. Hem i faet long su. Taem we him i go, ol man oli no

5 And James Gwero, seeking possible 'roads' of useful social connection as people in Vanuatu frequently do, probed further to discover whether or not Mr. Brown might, in particular, have been an Anglican chaplain. 
save luk. Taem i sut, ol man oli no save luk' (Lindstrom and White 1998: 127). Similarly, Raqraq Charlie of Malakula, a second heroic figure who features in a number of war stories, reportedly drew on his courage and his military friends to challenge Condominium authority (see also Moon and Moon 1998: 97-9). In addition to heroes, war stories also celebrate trickster themes that recall traditional stories of wily ancestors such as Remeto on Tanna. Tanna's Nase Kapaho, for instance, boasted his ability to elude pursuit by Condominium police forces during the war by hiding behind the American servicemen that he had befriended (Lindstrom 1989: 411). Such tricks allowed him to taunt Condominium police without fear of punishment.

A final and notable similarity between kastom and war stories concerns the role of song as a historical medium. Song, throughout the Pacific, is a 'formulary device' that memorialises important historical events, people, and places (Lindstrom 1990: 107-13; see Ong 1982; Charlot 1988). Ni-Vanuatu preserve important historical information in song as well as in story. Songs, like stories, help fix historical events, and also certain perspectives on this, in collective memory. Some songs stand alone as independent texts; others are incorporated as components of kastom stories. The two genres are linked in that many kastom stories incorporate one or more songs as important constituents. When we asked people to tell us their war stories, many would sing to us as well. In the midst of a story, a narrator might burst into song to elaborate some significant point or to document an important observation. Such songs function like place and personal names to add weight and consequence to a story.

We thus made a point to ask people if they recalled any songs from the warsongs that they themselves had composed or had learned from others. Some of these latter included popular mid-century American songs (e.g., You Are My Sunshine or the Marines Hymn - Dick Lautu knew many of these). Other songs were local compositions some of which, since the war, have remained popular and widely known. A favorite example is a song about Shepherd Islands and North Efate men who British District Officer Geoffrey Seagoe recruited to do the initial clearing of what today is Bauerfield. This song is variously attributed to Willie Bertie of Nguna, among others (Moon and Moon 1998: 48). We recorded one version performed by Wallace Kalaunapapa in Paunangisu; fieldworker Michael Matoa provided (through Kirk Huffman) a translation of several verses of this. This along with other songs about Big Wok that people continue to sing today complement a rich heritage of stories that preserve Vanuatu's wartime memories: ${ }^{6}$

6 Moon and Moon (1998: 48-49) cite more complete lyrics along with an English translation provided by Kalsaf Graham of Tongoa in March 1994. They also recorded a second version of the song in January 1994, sung by Tom Tasong and family from Tikilasoa, Nguna. 
Tai manga tu do dongo Vakalo

Endo pai taleva ni maramana

Ma tedo umai paki kuengida

E awi re te tunga vae esava

CHORUS:

Awi awi ri taimanga soldia teu rumai pak New Hebrides

Endape sara [Eu rumai pilaki] 'munition, eu pae United States of America

Rangi wain eurumai do town Vila

Epo masau tea suasua

En datango Hebrides thousand boy

Ngo Seagoe umai po musangi ngam

Tupei teaai sara nalauna

Efate, Nguna, Pele, Emau,

Mataso, Makura, Tongariki,

Tongoa, Malakula, Emae, Paama.

Brothers we used to hear about the war

On the other side of the world.

But it is coming to our country

Where are we going to go?

CHORUS:

Awi awi brothers, soldiers are coming to New Hebrides

They bring all sorts of ammunition; They come from United States of America.

When they came to Port Vila

They needed people to work

They asked for a thousand New Hebrides boys

And Seagoe came to pick us up

We are from many islands

Efate, Nguna, Pele, Emau,

Mataso, Makura, Tongariki,

Tongoa, Malakula, Emae, Paama.

Ol brata yumi harem faet

I stap nara saed long wol 
Working Together in Vanuatu

Mo i stap kam long ples blong yumi

Mo i wantem ol man blong go wok

CHORUS:

Sori tumas ol brata ol soldia oli kam long Niu Hebrides

Oli tekem amiunisin oli kam long United States of Amerika

Mifala ol man aelan ya

Efate, Nguna, Pele, Emau

Mataso, Makura, Tongariki

Tongoa, Malakula, Emae, Paama.

It is now 51 years after the end of the Pacific War. Most of the men and women who lived through the war in Vanuatu have now passed on - although not all. There are still older people with excellent memories and with good stories to tell. And many war stories and songs now have been passed down to children and grandchildren, becoming part of family and village memory. As time goes by, war stories are gradually changing into kastom stories. We were only able to record stories from some 125 people back in the 1980s. But there are many more friends and family members still out there with important stories to tell. Although the project officially ended back in 1989, I hope that VCC fieldworkers will continue to seek out, interview, and record war stories and songs to add these to the growing and cherished archive of Vanuatu's history.

\section{References}

Charlot, John, 1988. Some uses of chant in Samoan prose. Journal of American Folklore 101: 302-11.

Lacey, Roderic, 1980. Coming to know Kepai: conversational narratives and the use of oral sources in Papua New Guinea. Social Analysis 4: 74-88.

Lacey, Roderic, 1984. '...No Other Voice Can Tell': Life histories in Melanesia. International Journal of Oral History 5: 5-35.

Lindstrom, Lamont, 1989. Working encounters: oral histories of World War II Labor Corps from Tanna, Vanuatu. In The Pacific Theater: Island Representations of World War II, ed. Geoffrey M. White and Lamont Lindstrom, 395-417. Honolulu: University of Hawai'i Press.

Lindstrom, Lamont, 1990. Knowledge and Power in a South Pacific Society. Washington, DC: Smithsonian Institution Press. 
Lindstrom, Lamont, 1996. The American Occupation of the New Hebrides (Vanuatu). Macmillan Brown Working Paper Series No. 5. Christchurch: Macmillan Brown Centre for Pacific Studies, University of Canterbury.

Lindstrom, Lamont and James Gwero (eds), 1998. Big Wok: Storian blong Wol Wo Tu long Vanuatu. Suva: Institute of Pacific Studies, University of the South Pacific; Christchurch: Macmillan Brown Centre for Pacific Studies, University of Canterbury.

Moon, Margaret and Bruce Moon (eds), 1998. Ni-Vanuatu Memories of World War II. Diamond Harbour, NZ: Published by the authors.

Ong, Walter J., 1982. Orality and Literacy: The Technologizing of the Word. London: Methuen.

White, Geoffrey M., David Gegeo, Karen Ann Watson-Gego and David Akin (eds), 1988. Bikfala Faet: Olketa Solomon Aelanda Rimembaren. Wol Wo To/ The Big Death: Solomon Islanders Remember World War II. Suva: Institute of Pacific Studies, University of the South Pacific.

Zeleneitz, Marty and Hisafumi Saito, 1989. The Kilenge and the war: an observer effect on stories from the past. In The Pacific Theater: Island Representations of World War II, ed. Geoffrey M. White and Lamont Lindstrom, 167-84. Honolulu: University of Hawai'i Press. 